\title{
Effectiveness of Lecture and Discussion Teaching Methods in Teaching English Language through Figures of Speech Lok Raj Sharma ${ }^{1} \&$ Ram Nath Khanal ${ }^{2}$
}

${ }^{1} \mathrm{PhD}$ Scholar, Mewar University, Rajasthan, India

${ }^{2}$ Research Supervisor, Professor, Tribhuvan University, Kirtipur, Kathmandu, Nepal

Corresponding Author

Lok Raj Sharma

Email: lokraj043@gmail.com

\begin{abstract}
The main objective of this study is to identify the effectiveness of teaching methods in teaching English language through figures of speech. Thirty-one figures of speech were selected from different prose and verse lines for the study. The study was experimental in nature and the pretest-post test control group research design was adopted among 120 bachelor third year education students from five campuses of Makawanpur District, Nepal. Simple random sampling technique was used to select the students to form the Control Group and the Experimental Group which were taught by using the lecture teaching method and the discussion teaching method respectively for thirty five days. The paired samples $t$ test in SPSS Version 20 was used to compare Total Pretest Mean Score and Total Posttest Mean Score within groups. The overall reliability of the instruments based on the posttest scores of the students of the both groups of the pilot study was .979 and that of the research study was .968. The pair samples t test between the Total Pretest Mean Score and the Total Posttest Mean Score of the Control Group (observed $t$ - value= 20.652, critical $t$ - value $=2.001$ and $p<.05$ ) and the Experimental Group (observed $t$ - value $=42.907$, critical $t$-value $=2.001$ and $p<.05$ ) show that there was a statistically significant difference between the Total Pretest Mean Score and the Total Posttest Mean Score in each group. It justifies that the lecture teaching method and the discussion teaching method were effective within each group.
\end{abstract}

\section{KEYWORDS}

Discussion, Effectiveness, Language, Lecture, Teaching

\section{INTRODUCTION}

English is a foreign language in Nepal. Teaching a foreign language is a difficult task. Teaching literary language is even much more difficult than teaching ordinary language. The literary language is considered to be special and extra- ordinary, implicit and beyond the grasp of any objective linguistic analysis. Literary language involves a much greater degree of imagination than the language of common use. Teaching English language through figures of speech is one of the ways of turning an ordinary language into a literary language for creating emphatic, emotive and uncanny effects.

Figures of speech employed to teach literary language in this study were allegory, alliteration, anadiplosis, anaphora, apostrophe, assonance, climax, consonance, epiphora, euphemism, fable, hyperbole, irony, isocolon, litotes, metaphor, metonymy, onomatopoeia, oxymoron, parable, paradox, parody, personification, pun, rhetorical question, rhyme, sarcasm, satire, simile, symbol and synecdoche.

Figures of speech are present in all cultures and they may give birth to the different meanings. Culture is fundamentally related to language. Culture plays a central role in the way meanings are interpreted. Cultures are characterized by variability and diversity. Intercultural 
language teaching and learning focuses on the relationship between language, culture and learning. Learning languages is an intrapersonal and interpersonal process of meaning-making, interactional, developmental/dynamic interpretive, imaginative and creative.

Teaching method refers to a combination of instructional methods, learning activities, and materials that actively engage students and appropriately reflect both learning goals and students' developmental needs. Teaching methods are considered to play a pivotal role to affect the students' understanding of the subject matters and their test scores. Some students assert that the lecture teaching method is more appropriate and effective for the bachelor level students, whereas some students prefer the discussion teaching method for their active participation in learning things. This research concludes that both the lecture teaching method and the discussion teaching method were effective within the groups, but the discussion teaching method was more effective than the lecture teaching method in teaching literary English language using figures of speech.

Lecture as a teaching method is the oldest traditional mode of teaching almost all the subjects of the curriculum at all levels. It aims at attaining the specific teaching learning objectives related to the cognitive and affective domains of the learner's behaviour. The group discussion method involves some sort of discussion for exchanging ideas between students and the teacher or among a group of students resulting in some learning for the realization of the predetermined teaching learning objectives.

Teaching is an art of assisting and facilitating students to learn the subject matter. All good teaching is characterized by a proper teaching method despite diverse teaching methods that have been adopted and practiced in the field of English language teaching. Teaching language is a complex task and teaching literary English language is both interesting and tough. The researcher adopted two teaching methods the lecture teaching method for teaching the students of the Control Group and the discussion teaching method for teaching the students of the Experimental Group at five different campuses which are situated in Makawanpur District, Nepal. This district is regarded as the fruitful vicinity for college education, because students from different geographical locations, diverse cultures, castes, family backgrounds, religions and political dogmas come for their higher education. The researcher assumes that such students may represent almost all the students studying in different campuses of the nation.

\section{Objectives of the Research Study}

The objectives of the study were:

a. To investigate the effectiveness of the lecture teaching method in teaching English language to the Control Group through figures of speech.

b. To examine the effectiveness of the discussion teaching method in teaching English language to the Experimental Group through figures of speech.

\section{Null Hypotheses of the Research Study}

a. There is no statistically significant difference between the Total Posttest Mean Score and the Total Pretest Mean Score of the Students of the Control Group.

b. There is no statistically significant difference between the Total Posttest Mean Score and the Total Pretest Mean Score of the Students of the Experimental Group. 


\section{LITERATURE REVIEW}

Literature review encompasses definition of teaching, some advantages and disadvantages of lecture teaching method, some advantages and disadvantages of discussion teaching method, definitions of the figures of speech employed in the research study.

\section{Teaching}

Teaching is both an art and science. Centra (1993) asserts that teaching is an intellectual process that "produces beneficial and purposeful student learning through the use of appropriate procedures" (p.42). Furthermore, the process of teaching involves the transmission of knowledge/theory, or the teaching skills. Jarvis (2002) considers teaching to be an "instrumentally rational activity" (p.40). Teaching can be effective or ineffective. Braskamp and Ory (1994) assume an effective teaching to be "the creation of situations in which appropriate learning occurs, shaping those situations is what successful teachers have learned to do effectively" (p.40). The act of teaching and learning is complex and the role of a teacher is not one of simply receiving prescriptions from others that are subsequently 'implemented' in their context. Rather the teacher comes to the act of teaching and learning with his own self-motivated framework of knowledge and understanding of his own personal, social, cultural and linguistic make-up and that of his students.

\section{Some Advantages and Disadvantages of Lecture Teaching Method}

There are some advantages and some disadvantages of lecture teaching method. Williams (2002) opines lecture to be "a particular type of educational encounter in which a teacher transmits information to a number of students" (p.3). Lecture method allows more materials to be covered, in particular the multiple and varied exemplars that have been associated with superior acquisition and transfer. For Capon and Kuhn (2004), lecture method is "the most economical method of transmitting knowledge". The teacher's enthusiasm and commitment to the subject in a lecture motivate the students to listen attentively and learns the lesson positively. Lecturing is versatile because any subject area can be taught through lecture.

Al-Modhefer and Roe ( 2009 \& 2010) point out the demerits of lecture method with this remark "lectures can be passive, outdated, rigid, one-way and ineffective routine knowledge transmission". Learning is very difficult to judge. Killen (2007) views that in lecture method "there is little check of learner understanding" (p.128). Pure lecture fails to give feedback to both the teacher and the learners. Lecture-based instructional method is the one-way process of teaching and it does not allow students in verbal participation during the lecture. In this method, it is very difficult for the teacher to hold the attention of the whole class during the lecture. Effectiveness of lecture-based instructional method needs significant skills in speaking.

\section{Some Advantages and Disadvantages of Discussion Teaching Method}

According to Stewart, et al.( 2010), discussion, a hybrid form of teaching because students give and receive information, is often considered "the prototypic method and core component of active teaching learning". Similar concept was expressed by Whetten and Clark, 1996) in their articles. Marbach-Ad, Seal and Sokolove (2001) and Jungst, Licklider and Wiersema (2003) point out that "despite the fact that most faculty and students do have preference for the lecture method, many educators believe that the traditional lecture approach to teaching is ineffective compared to active learning methods". Discussion is one of the active teaching and learning methods. There are some demerits of the discussion teaching method. The group discussion may go out of track without paying proper concentrations to the set objectives. The inactive or shy 
member may not show any interest in the discussion. Sometimes unnecessary interference may take place in the thought process.

\section{Figures of Speech}

A figure of speech is a mode of expression in which words are used out of their literal meaning or out of their ordinary use in order to add beauty or emotional intensity to transfer the writer's sense expression by comparing and identifying one thing with another. A figure of speech refers to a certain conventional literary device that has been used by the literary writers and poets to create a special meaning and unique form. The use of a figure of speech turns an ordinary language into figurative language which creates an artistic effect in the writings and speech. Figures of speech are used to describe the devices employed to add color, decoration and imaginative expression to linguistic use. Wren and Martin (1981) view figure of speech as "a departure from the ordinary form of expression or the ordinary course of ideas in order to produce a greater effect" (p.488). The following figures of speech were employed in the research study.

\section{Allegory}

Cuddon (1999) defines an allegory as "a story in verse or prose with a double meaning: a primary meaning and a secondary meaning" (p.20). Example: The story of Icarus

Icarus fashions wings for himself out of wax, but when he flies too close to the sun his wings melt. This story is a message about the dangers of reaching beyond one's powers.

\section{Alliteration}

Wales (2001) opines that alliteration is "the repetition of the initial consonant in two or more words" (p.14). Example: Sita sings a sweet song.

In this sentence, the consonant sound / s / is repeated in the initial position of the words "Sita", "sings", "sweet" and "song".

\section{Anadiplosis}

Cuddon (1999) affirms anadiplosis as "the repetition of the last word of one clause at the beginning of the following clause to gain a special effect" (p.34). Example: I helped Ram. Ram helped Shyam. Shyam won the game.

The last word of the first sentence "Ram" occurs as the first word of the second sentence. Similarly, the last word of the second sentence "Shyam" has come as the first word of the third sentence.

\section{Anaphora}

Wales (2001) considers that anaphora is "a popular figure of speech involving repetition of the same word at the beginning of successive clauses, sentences or verses" (p.19). Example:

Go back to Mississippi, go back to Alabama, go back to South Carolina, go back to Georgia, go back to Louisiana, go back to the slums and ghettos of our northern cities, knowing that somehow this situation can and will be changed. (Martin Luther King Jr: I have a Dream) This extract contains the repetition of the phrase "go back to" many times. The whole speech is full of the anaphoric example. He encourages the black people to go back to their respective places, believing that the bad situation will be changed one day.

\section{Apostrophe}

Cuddon (1999) defines apostrophe as "a figure of speech in which a thing, a place, an abstract quality, a dead or absent person, is addressed as if present and capable of understanding" (p.51).

Example:

Death, be not proud, though some have called thee

Mighty and dreadful, for thou are not so; 
For those whom thou think'st thou dost overthrow

Die not, poor Death, nor yet canst thou kill me. (Donne: Holy Sonnet 10)

Donne addresses Death and tells it not to be proud. Though some people called it powerful and terrible, it is not powerful and it can't kill him.

\section{Assonance}

Abrams (1993) contends assonance as "the repetition of identical or similar vowel sounds especially in stressed syllable in a sequence of nearby words" (p.7). Example:

Stem end and blossom end, And every fleck of russet showing clear. (Robert Frost: After Apple-Picking)

We notice the repetition of the short vowel /e/ in the words "stem", "end", "every" and "fleck" in the poetic lines.

\section{Climax}

Cuddon (1999) opines that climax is "the part of a story or play at which a crisis is reached and resolution is achieved" (p. 141). Example:

This note was a promise that all men, yes, black men as well as white men, would be guaranteed the unalienable Rights of Life, Liberty and the pursuit of Happiness. (Martin Luther King: I Have a Dream)

The pursuit of happiness is the climax bestowed by the Rights as mentioned by Luther King.

\section{Consonance}

Cuddon (1999) remarks consonance "the close repetition of the identical consonant sounds before and after different vowel sounds" (p. 176). Example: Thin men sat on a mat under a fan There is the repetition of the consonant sound / n / in the words "Thin", "men", "under" and "fan" that retain different vowel sounds.

\section{Epiphora}

Cuddon (1999) defines epiphora as "a figure of speech in which each sentence or clause ends with the same word" (p.279). Example:

If you had known the virtue of the ring,

Or half her worthiness that gave the ring,

Or your own honor to contain the ring,

You would not then have parted with the ring. (Shakespeare: The Merchant of Venice)

Shakespeare uses the phrase "the ring" in his famous play "The Merchant of Venice". He makes his characters use the ring again and again in the dialogues to stress the significance of the ring.

\section{Euphemism}

Abrams (1993) asserts that "euphemism is an inoffensive expression used in place of a blunt one that is felt to be disagreeable or embarrassing" (p.60). Example:

Lo! The baby is in the state of nature,

So lively, so benign, and so innocent. (1-2) (Sharma: The Baby)

In the first line, "in the state of nature" is a mild and pleasant phrase that is used to substitute for a harsh, blunt, or offensive term "naked". It is an instance of euphemism.

\section{Fable}

Cuddon (1999) asserts that fable is "a short narrative in prose or verse which points a moral" (p.300).

Example: "A crow was sitting on a branch of a tree with a piece of cheese in her beak when a fox observed her and set his wits to work to discover some way of getting the cheese. Coming and standing under the tree he looked up and said, 'What a noble bird I see above me! Her beauty is 
ISSN: 2362-1303 (Paper) | eISSN: 2362-1311 (Online)

JOURNAL OF ADVANCED ACADEMIC RESEARCH (JAAR)

without equal...' Down came the cheese, of course, and the Fox, snatching it up, said, 'You have a voice madam, I see: what you want is wits."' (Aesop: The Fox and the Crow)

Aesop is probably the most notable author of famous examples of fable. Aesopian fables put emphasis on the social communications of human beings, and hence the morals he draws deal with realities of life. In this excerpt, Aesop gives a moral lesson that flatterers must not be trusted.

\section{Hyperbole}

Abrams (1993) asserts that the "figure of speech or trope, called hyperbole is a bold overstatement, or the extravagant exaggeration of fact or of possibility; it may be used either for serious or ironic or comic effect" (p. 85). Example:

Ten thousand saw I at a glance,

Tossing their heads in a sprightly dance. (Wordsworth: Daffodils)

The speaker mentions that he saw at a glance ten thousand daffodils moving their heads in a lively dance. Here, ten thousand daffodils mean too many daffodils - too difficult to be counted. It is an exaggeration of fact.

Irony

Cuddon (1999) views irony to be "the most precious and efficient weapon of the satirist" (p.431).

Example:

Do not weep, maiden, for war is kind,

Because your lover threw wild hands toward the sky

And the affrighted steed ran on alone,

Do not weep.

War is kind. (1-5) (Crane: War is Kind)

The speaker tells a maiden not to weep because war is kind. But the word "kind" is used ironically. In fact, he means to say that war is cruel and it enjoys killing the warriors. The given lines employ irony.

\section{Isocolon}

Longaker and Walker (2011) define isocolon as "the repetition of equivalent phrase or clause structures" (p. 148). Example:

What the hammer? What the chain,

In what furnace was thy brain?

What the anvil? What dread grasp, Dare its deadly terrors clasp! (Blake: The Tyger)

William Blake's short poem "The Tyger" retains the example of isocolon which involves the repetition of "What the + noun" such as "what the hammer", "what the chain" and "what the anvil.". The "hammer" and "chain" are very similar semantically, just as "anvil" and "dread grasp" are.

\section{Litotes}

Harmon (2009) views litotes as "a form of understatement in which a thing is affirmed by stating the negative of its opposite" (p.297). Example:

"I am not unaware how the productions of the Grub Street brotherhood have of late years fallen under many prejudices." (Swift: A Tale of a Tub)

Swift has used double negatives to emphasize the point that he is totally aware of it. The irony is that he is aware, but he is saying it as if he is unaware that he is. 
ISSN: 2362-1303 (Paper) | eISSN: 2362-1311 (Online)

JOURNAL OF ADVANCED ACADEMIC RESEARCH (JAAR)

June 2019

\section{Metaphor}

A metaphor is a rhetorical figure of speech that compares two subjects without the use of "like" or "as." Metaphor is a figure of speech in which one thing is described in terms of another. Barber (1985) defines that metaphor is "one of the powerful tools that poets use, but it is but no means confined to poetry: it also occurs in prose and speech" (p.42). Example:

AII the world's a stage;

And all the men and women merely players. (William Shakespeare: As you Like It)

"All the world is a stage" is a good example of metaphor. In this example, 'the world' is compared with 'a stage'. The aim is to describe the world by taking well-known attributes from the stage. We are all players performing particular roles.

\section{Metonymy}

Cuddon (1999) considers metonymy as "a figure of speech in which the name of an attribute or a thing is substituted for itself' (p.510). Example: The pen is mightier than the sword. (Proverb)

In the example above, the word "pen" and "sword" have replaced "written words" and "military "force".

\section{Onomatopoeia}

Simpson (2004) views onomatopoeia as a "feature of sound patterning which is often thought to form a bridge between style and content" (p.67). Example:

ARIEL:

Hark, hark!

Bow-wow.

The watch-dogs bark!

Bow-wow.

Hark, hark! I hear

The strain of strutting chanticleer

Cry, 'cock-a-doddle-doo!' (Shakespeare: The Tempest)

The character Ariel says that the dogs bark "bow-wow", while the chanticleer cries "cock-adoddle-doo." These words imitate the noises of two animals.

\section{Oxymoron}

Cuddon (1999) views that oxymoron is a figure of speech which "combines incongruous and apparently contradictory words and meanings for a special effect” (p.627). Example:

A damned saint, an honourable villain!

$\mathrm{O}$, nature! what hadst thou to do in hell

When thou didst bower the spirit of a fiend" ( Shakespeare: Romeo and Juliet, Act I, Scene II ) This extract makes use of good oxymora, such as "damned saint" and "honorable villain".

\section{Parable}

Cuddon (1999) defines parable as "a short and simple story, related to allegory and fable, which points a moral" (p.654). Example: The Parable of the Sower (The Bible: Matthew 13:3-9).

Jesus often compared the kingdom of God to a seed planted in the hearts of men and women. Each of us has the seed of the kingdom within us, but it will grow only if we give it the proper "care and feeding." Jesus tells of this aspect of the kingdom in His Parable of the Sower.

\section{Paradox}

Abrams (1993) remarks that paradox as "a statement which seems on its face to be selfcontradictory or absurd yet turns out to make good sense" (p.140). Example:

Success is counted sweetest

By those who ne`er succeed. (Dickinson: Success Is Counted Sweetest) 
ISSN: 2362-1303 (Paper) | eISSN: 2362-1311 (Online)

JOURNAL OF ADVANCED ACADEMIC RESEARCH (JAAR)

June 2019

The above poetic lines mean that the people who never succeed count that success is the sweetest thing, but those who succeed think that their success is not sufficient. They desire more .This excessive desire makes them feel that this success is not so sweet. The thing we achieve remains uncounted.

Parody

Wales ( 2001)) states parody can be seen as "a kind of imitation which borrows the style and technique of a text or the writer's idiolect and fits new subject matter to it, often for a humorous or satirical purpose"(p.286). Example: "Gretel" by Garrison Keillor

The story entitled "Gretel" by Garrison Keillor is a parody of the fairy tale "Hansen and Gretel" of Jacob and Wilhelm Grimm. Both the fairy tales deal with the struggle of two children Hansen and Gretel in different ways.

\section{Personification}

Wales (2001) assumes personification as "a figure of speech or trope in which an inanimate object, animate non-human or abstract quality is given human attributes" (p. 294). Example:

The sky said to the earth, "I will marry you".

"The sky" as a matured man expresses his desire to marry "The earth" as a girl.

\section{Pun}

Cuddon (1999) defines pun as "a figure of speech which involves a play upon words. The pun is wide spread in many literatures and gives rise to a fairly universal form of humor" (p.711). Example:

And even the stable boy will find

This life no stable thing. (Hood: Death in the Kitchen)

Here , the poet has used the homonymous word "stable" two times . It carries two different meanings. One is "working at a stable." and another is "constant".

\section{Rhetorical Question}

Wales (2001) assumes the rhetorical question as "a question which does not expect an answer, since it really asserts something which is known to the addresser and can't be denied" (p.346).

Example:

"If you prick us, do we not bleed?

If you tickle us, do we not laugh?

If you poison us, do we not die?

And if you wrong us, shall we not revenge?" (Shakespeare: The Merchant of Venice)

Shakespeare uses the rhetorical questions not to seek the answer, but uses them to make his point strong.

\section{Rhyme}

Harmon (2009) defines the rhyme as "the identity of terminal sound between accented syllables, usually occupying corresponding positions in two or more lines of verse" (p.449). Example:

I listened, motionless and still;

And, as I mounted up the hill,

The music in my heart I bore

Long after it was heard no more. (Wordsworth: The Solitary Reaper)

Here, "still" and "hill", and similarly, "bore" and "more" are monosyllabic words which rhyme with each other in pairs. These pairs of words have masculine rhyme: beat / heat, die / lie, book/ took, kill/ fill etc. 


\section{Sarcasm}

Brown (1993) defines sarcasm as "a bitter or wounding expression or remark, a taunt, esp. one ironically worded" (p.268). Example:

Your son dropped a vase and it broke down. You say," You have done a good job." It is a sarcasm.

Satire

Cuddon (1999) defines satire as "a kind of protest, a sublimation and refinement of anger and indignation" p.780). Example: We are proud of our political leaders. They are always worried about the people. It is a satirical remark. It means to expose the reality of our leaders that they are selfish and careless. They never think of their people's well-being.

\section{Simile}

Wales (2001) views simile as "a figure of speech whereby two concepts are imaginatively and descriptively compared" (p.358). Example: Rita is like a rose.

Rita is compared with a rose to show that she is beautiful.

\section{Symbol}

Cuddon (1999) assumes symbol as "an object, animate or inanimate, which represents or stands for something else" (p. 885). Example:

O Rose, thou art sick!

The invisible worm,

That files in the night,

In the howling storm,

Has found out thy bed

Of crimson joy;

And his dark secret love

Does thy life destroy. (Blake: The Sick Rose)

This brief poem by Blake is quite symbolic. Here 'Rose' is a symbol of beauty, youth, innocence, female quality etc., whereas 'the worm' a symbol of experience, male quality, destructive force etc.

\section{Synecdoche}

Wales (2001) opines synecdoche as "a trope in rhetoric in which part of a referent is named and stands for the whole or vice versa" (p.382). Example: Brazil won the football match.

"Brazil" is a synecdoche. It refers to the Brazilian football players. Brazil as a nation represents the wholeness that is used to indicate its players as its part.

\section{RESEARCH METHOD}

A research method is a systematic plan for conducting research. It embraces the following aspects:

\section{Research Design}

A pretest-posttest control group research design was used to carry out the study. The researcher collected data from the pretest and posttest question items based on thirty-one figures of speech.

\section{Sampling Design}

The researcher followed two-stage cluster sampling design which involved selecting all five campuses out of five campuses as clusters as the rule of determining sample size. Then all the students within each cluster were selected into the Control Group and the Experimental Group through simple random sampling design, especially the lottery method. 


\section{Population and Sample Size of the Research Study}

All the B.Ed. third year students (122) studying English as a major subject at five campuses in Makawanpur District, Nepal, constituted the population. The sample size involved 120 students who were equally divided into two groups namely, the Control Group and the Experimental Group considering all the campuses as a whole.

\section{Students Involved from Five Campuses in the Study}

Simple random sampling technique was used to select 120 students (19 boys and 101 girls) for the study from five campuses in Makawanpur District, Nepal.

Table 1: Students in the Experimental Group and the Control Group

\begin{tabular}{|c|c|c|c|c|c|c|}
\hline \multirow[t]{2}{*}{ Area } & \multirow[t]{2}{*}{ Campuses } & \multicolumn{2}{|c|}{ Experimental Group } & \multicolumn{2}{|c|}{ Control Group } & \multirow[t]{2}{*}{ Total } \\
\hline & & Boys & Girls & Boys & Girls & \\
\hline \multirow[t]{2}{*}{ Urban } & $\begin{array}{l}\text { Makawanpur Multiple } \\
\text { Campus ( MMC) }\end{array}$ & 6 & 9 & 2 & 13 & 30 \\
\hline & Hetauda Campus (HC) & 5 & 13 & 3 & 15 & 36 \\
\hline \multirow[t]{3}{*}{ Rural } & $\begin{array}{l}\text { Banshagopal Multiple } \\
\text { Campus (BMC) }\end{array}$ & 0 & 12 & 2 & 10 & 24 \\
\hline & $\begin{array}{l}\text { Hatiya Janapriya Multiple } \\
\text { Campus (HJMC) }\end{array}$ & 0 & 7 & 0 & 7 & 14 \\
\hline & $\begin{array}{l}\text { Nirmal Multiple Campus } \\
\text { (NMC) }\end{array}$ & 1 & 7 & 0 & 8 & 16 \\
\hline \multicolumn{2}{|r|}{ Total } & 12 & 48 & 7 & 53 & 120 \\
\hline
\end{tabular}

The Table 1 shows that there were 12 boys and 48 girls in the Experimental Group. Similarly, 7 boys and 53 girls were in the Control Group. Each group had 60 students.

\section{Age Groups of the Students}

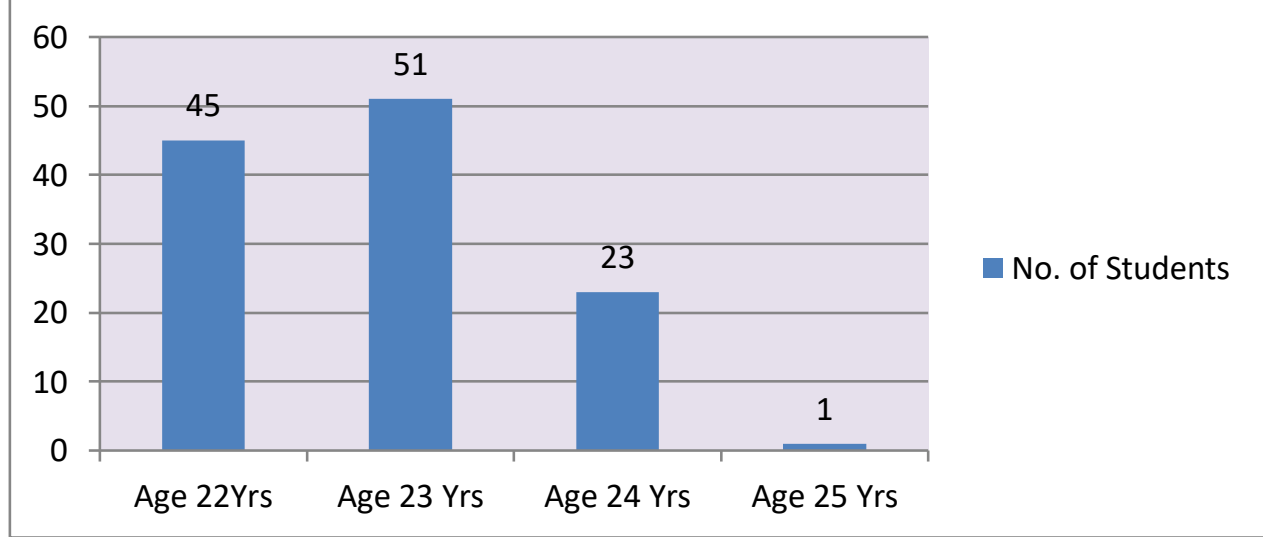

Figure 1. Total Number of the Students with their Age 
There were 19 male and 101 female students aged between 22- 25 years. 45 students belonged to the age of 22, 51 students belonged to the age of 23, 23 students belonged to the age of 24 and 1 students belonged to the age of 25 (Figure 1).

\section{Religions of the Students}

100 students belonged to Hinduism, 14 students belonged to Buddhism and 6 students belonged to Christianity. The following figure shows the percentages of students by religion.

\section{Percent of Students by Religion}

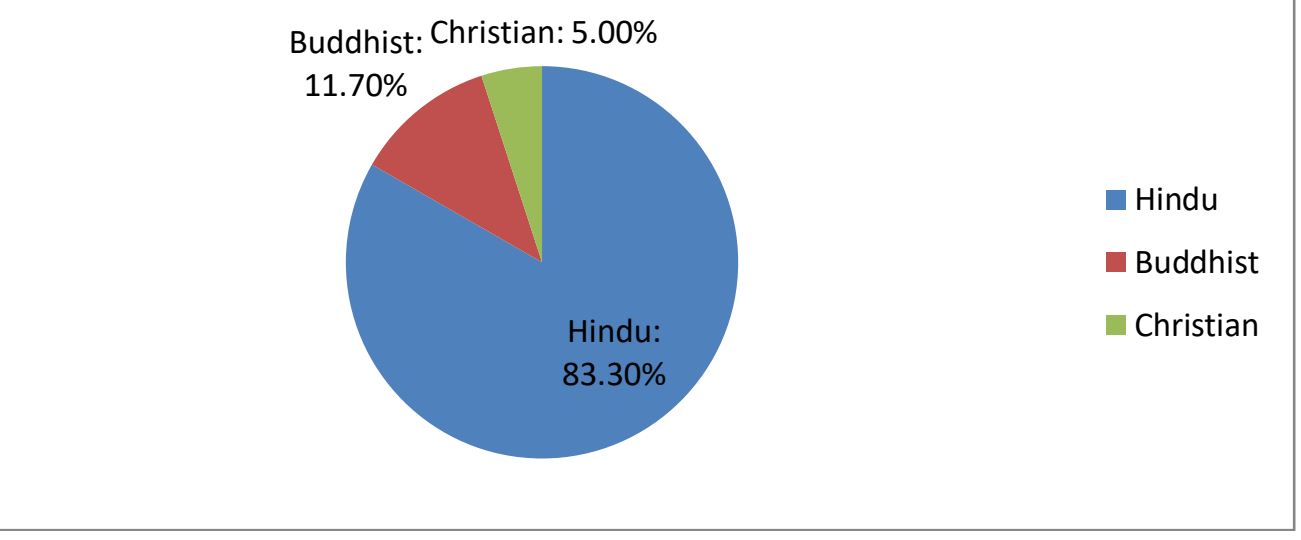

Figure 2: Percentages of Students by Religions in the Study Sample

Figure 2 shows that most of the students who were involved in my research came from the families of Hindu religion.

\section{Instruments of the Study}

The researcher constructed hundred multiple choice question items based on figures of speech.

\section{Procedure}

After the formation of the Control Group and the Experimental Group at each campus, the researcher administered the pretest for both groups. The same pretest question items were asked to both groups. The pretest scores of the both groups were maintained carefully on the ratio scale. The Control Group was taught by using the lecture teaching method, whereas the Experimental Group was taught by using the discussion teaching method for thirty days. After finishing the teaching activity, the researcher administered the posttest for both groups. Both the pretest and the posttest question items were the same. The posttest scores of both groups were recorded on ratio scale for making analysis and comparison with their pretest scores.

\section{Validity of the Instruments}

To measure the validity of the instruments, the researcher received opinions and judgments from subject experts and authorities. In this way, the validity of the instruments was maintained.

\section{Reliability of the Instruments}

The researcher used the Split-Half model of reliability to check the reliability of the instruments. The reliability of the instruments based on the posttest scores of the students of the Control Group of the pilot study was .919 and that of the Experimental Group was .994. The overall internal consistency on the posttest scores of the students of both groups of the pilot study was .979. The reliability of the instruments based on the posttest scores of the students of the Control Group of the research study was .909 and that of the Experimental Group was .913. The overall internal consistency on the posttest scores of the students of both groups of the research study 
ISSN: 2362-1303 (Paper) | eISSN: 2362-1311 (Online)

JOURNAL OF ADVANCED ACADEMIC RESEARCH (JAAR)

was .968. It shows us that the instruments were highly reliable in measuring students' achievement in English language learning.

\section{Variables in the Study}

The lecture teaching method used to teach the Control Group and the discussion teaching method used to teach the Experimental Group were the independent variables and the test scores of the students of the both groups were the dependent variables.

\section{Analysis of Data}

All the data were analyzed by using Statistical Package for Social Sciences (SPSS) 20 version. The researcher used paired samples $t$ test to examine whether there was a statistically significantly different between the total mean scores of the Control Group and the Experimental Group at five individual campuses and the campuses as a whole. The researcher made use of $G$ Power 3.1 Software to measure the power of the hypothesis test.

\section{RESULT AND DISCUSSION}

The findings were interpreted based on the total mean scores, and the paired samples $t$ test of question items was applied to the Control Group and the Experimental Group.

\section{Control Group}

It is the group of students who were taught through the lecture teaching method as the independent variable in the study. The total pretest score and the total posttest score were the paired variables.

\section{Analysis of Paired Samples T- Test of Control Group}

Table 2: Paired Variables: Total Posttest Score and Total Pretest Score Group: Control

\begin{tabular}{|c|c|c|c|c|c|c|c|c|c|}
\hline $\begin{array}{l}\text { Campus } \\
\text { es }\end{array}$ & Score & Mean & $\mathbf{N}$ & $\begin{array}{l}\text { Std. } \\
\text { Deviatio } \\
\text { n }\end{array}$ & $\begin{array}{l}\text { Std } \\
\text { Error } \\
\text { Mean }\end{array}$ & $\begin{array}{l}\text { Table } \\
\mathbf{t} \\
\text { Value }\end{array}$ & $\begin{array}{l}\text { Observed } \\
\mathbf{t} \\
\text { Value }\end{array}$ & Df & $\begin{array}{l}\text { Sig. (2- } \\
\text { tailed) }\end{array}$ \\
\hline \multirow[t]{2}{*}{ MMC } & $\begin{array}{l}\text { Total } \\
\text { Posttest }\end{array}$ & 45.000 & 15 & 6.740 & 1.740 & \multirow{2}{*}{2.144} & \multirow{2}{*}{12.550} & \multirow{2}{*}{14} & \multirow{2}{*}{.000} \\
\hline & $\begin{array}{l}\text { Total } \\
\text { Pretest }\end{array}$ & 21.000 & 15 & 2.104 & .543 & & & & \\
\hline \multirow[t]{2}{*}{ HC } & $\begin{array}{l}\text { Total } \\
\text { Posttest }\end{array}$ & 45.944 & 18 & 7.688 & 1.812 & \multirow{2}{*}{2.109} & \multirow{2}{*}{12.569} & \multirow{2}{*}{17} & \multirow{2}{*}{.000} \\
\hline & $\begin{array}{l}\text { Total } \\
\text { Pretest }\end{array}$ & 19.500 & 18 & 2.854 & .672 & & & & \\
\hline \multirow[t]{2}{*}{ BMC } & $\begin{array}{l}\text { Total } \\
\text { Posttest }\end{array}$ & 48.833 & 12 & 7.505 & 2.166 & \multirow{2}{*}{2.200} & \multirow{2}{*}{6.380} & \multirow{2}{*}{11} & \multirow{2}{*}{.000} \\
\hline & $\begin{array}{l}\text { Total } \\
\text { Pretest }\end{array}$ & 32.666 & 12 & 2.870 & .828 & & & & \\
\hline \multirow[t]{2}{*}{ НЈМС } & $\begin{array}{l}\text { Total } \\
\text { Posttest }\end{array}$ & 44.857 & 7 & 6.309 & 2.384 & \multirow{2}{*}{2.446} & \multirow{2}{*}{8.466} & \multirow{2}{*}{6} & \multirow{2}{*}{.000} \\
\hline & $\begin{array}{l}\text { Total } \\
\text { Pretest }\end{array}$ & 24.142 & 7 & 2.911 & 1.100 & & & & \\
\hline NMC & $\begin{array}{l}\text { Total } \\
\text { Posttest }\end{array}$ & 46.750 & 8 & 6.135 & 2.169 & 2.364 & 11.984 & 7 & .000 \\
\hline
\end{tabular}


ISSN: 2362-1303 (Paper) | eISSN: 2362-1311 (Online)

JOURNAL OF ADVANCED ACADEMIC RESEARCH (JAAR)

June 2019

\begin{tabular}{|l|l|l|l|l|l|l|l|l|l|}
\hline & $\begin{array}{l}\text { Total } \\
\text { pretest }\end{array}$ & 19.625 & 8 & 2.386 & .843 & & & & \\
\hline
\end{tabular}

Table 2 shows that the observed t value was greater than the table value or critical value at all campuses. Similarly, Sig (2-tailed) or the value of probability was smaller than .05 at all campuses. It shows that there was a statistically significant difference in the total pretest mean score and the total posttest mean score of the Control Group at each campus. It shows the rejection of null hypothesis resulting in the acceptance of the alternative hypothesis. It further justifies that the lecture teaching method was effective within each campus.

The researcher considered five campuses as a whole to investigate whether there was a statistically significant difference between the total pretest mean score and the total posttest mean score of the students of the Control Group or not.

Table 3: Paired Variables: Total Posttest Score and Total Pretest Score Group: Control

\begin{tabular}{|l|l|l|l|l|l|l|l|l|l|}
\hline $\begin{array}{l}\text { Campus } \\
\text { es }\end{array}$ & Score & Mean & $\mathbf{N}$ & $\begin{array}{l}\text { Std. } \\
\text { Deviatio } \\
\mathbf{n}\end{array}$ & $\begin{array}{l}\text { Std } \\
\text { Error } \\
\text { Mean }\end{array}$ & $\begin{array}{l}\text { Table } \\
\text { t } \\
\text { Value }\end{array}$ & $\begin{array}{l}\text { Observed } \\
\text { t } \\
\text { Value }\end{array}$ & $\begin{array}{l}\text { Df } \\
\text { tailed) }\end{array}$ \\
\cline { 1 - 8 } $\begin{array}{l}\text { As a } \\
\text { Whole }\end{array}$ & $\begin{array}{l}\text { Total } \\
\text { Posttest }\end{array}$ & 46.266 & 60 & 6.991 & .902 & 2.001 & 20.652 & 59 & .000 \\
\cline { 2 - 5 } & $\begin{array}{l}\text { Total } \\
\text { Pretest }\end{array}$ & 23.066 & 60 & 5.650 & .729 & & & \\
\hline
\end{tabular}

The pair samples t test between the total pretest mean score and the total posttest mean score of the Control Group of campuses as a whole (observed t- value $=20.652$, critical $t$ - value $=2.001$, $\mathrm{Df}=59$ and $\mathrm{Sig}(2$-tailed) or $\mathrm{p}<.05)$ shows that there was a statistically significant difference between the total pretest mean score and the total posttest mean score. It rejects the null hypothesis "there is no statistically significant difference between the Total Posttest and the Total Pretest Mean Scores of the students of the Control Group". It justifies that the lecture teaching method was effective within the Control Group (Table 3).

Power of Hypothesis Test in the Control Group

The researcher made use of G Power 3.1 Software to measure the power of the hypothesis test.

Table 4: Power of Hypothesis Test

\begin{tabular}{|lll|}
\hline \multicolumn{2}{|l|}{ T-tests - Means: Difference between two dependent means (matched pairs) } \\
Analysis: & Post hoc: Compute achieved & power \\
Input: & Tail(s) & Two \\
& Effect size dz & $=2.6661028$ \\
& $\alpha$ err prob & $=0.05$ \\
& Total sample size & $=60$ \\
Output: $\quad$ Noncentrality parameter $\delta$ & $=20.6515435$ \\
& Critical t & $=2.0009954$ \\
& D & $=59$ \\
& Power (1- $\beta$ err prob) & \\
& &
\end{tabular}

The power of the hypothesis test (1- $\beta$ err prob) as shown in the table was 1.000 which indicates that the test was considered to be working perfectly well. It implies that there was $100 \%$ chance 
ISSN: 2362-1303 (Paper) | eISSN: 2362-1311 (Online)

JOURNAL OF ADVANCED ACADEMIC RESEARCH (JAAR)

of correctly rejecting the null hypothesis (H0) and accepting the alternative hypothesis (H1) with 60 students (Table 4).

\section{Experimental Group}

It is the group of students who were taught through the discussion teaching method that works as a treatment or independent variable in the study. The total pretest score and the total posttest score were the paired variables.

\section{Analysis of Paired Samples T- Test of Experimental Group}

Table 5: Paired Variables: Total Posttest Score and Total Pretest Score Group

Experimental

\begin{tabular}{|c|c|c|c|c|c|c|c|c|c|}
\hline $\begin{array}{l}\text { Campus } \\
\text { es }\end{array}$ & Score & Mean & $\mathbf{N}$ & $\begin{array}{l}\text { Std. } \\
\text { Deviat } \\
\text { ion } \\
\end{array}$ & $\begin{array}{l}\text { Std } \\
\text { Error } \\
\text { Mean } \\
\end{array}$ & $\begin{array}{l}\text { Table } \\
\mathrm{t} \text { - } \\
\text { Value } \\
\end{array}$ & $\begin{array}{l}\text { Observed } \\
\text { t- } \\
\text { Value } \\
\end{array}$ & Df & $\begin{array}{l}\text { Sig. (2- } \\
\text { tailed) }\end{array}$ \\
\hline \multirow[t]{2}{*}{ MMC } & $\begin{array}{l}\text { Total } \\
\text { Posttest }\end{array}$ & 64.466 & 15 & 2.614 & .675 & \multirow{2}{*}{2.144} & \multirow{2}{*}{30.787} & \multirow{2}{*}{14} & \multirow{2}{*}{.000} \\
\hline & $\begin{array}{l}\text { Total } \\
\text { Pretest }\end{array}$ & 21.800 & 15 & 3.648 & .942 & & & & \\
\hline \multirow[t]{2}{*}{ HC } & $\begin{array}{l}\text { Total } \\
\text { Posttest }\end{array}$ & 73.166 & 18 & 4.514 & 1.064 & \multirow{2}{*}{2.109} & \multirow{2}{*}{41.274} & \multirow{2}{*}{17} & \multirow{2}{*}{.000} \\
\hline & $\begin{array}{l}\text { Total } \\
\text { Pretest }\end{array}$ & 19.555 & 18 & 3.518 & .829 & & & & \\
\hline \multirow[t]{2}{*}{ BMC } & $\begin{array}{l}\text { Total } \\
\text { Posttest }\end{array}$ & 67.000 & 12 & 5.608 & 1.619 & \multirow{2}{*}{2.200} & \multirow{2}{*}{24.236} & \multirow{2}{*}{11} & \multirow{2}{*}{.000} \\
\hline & $\begin{array}{l}\text { Total } \\
\text { Pretest }\end{array}$ & 30.666 & 12 & 2.534 & .731 & & & & \\
\hline \multirow[t]{2}{*}{ НЈМС } & $\begin{array}{l}\text { Total } \\
\text { Posttest }\end{array}$ & 68.142 & 7 & 4.488 & 1.696 & \multirow{2}{*}{2.446} & \multirow{2}{*}{23.395} & \multirow{2}{*}{6} & \multirow{2}{*}{.000} \\
\hline & $\begin{array}{l}\text { Total } \\
\text { Pretest }\end{array}$ & 23.428 & 7 & 3.952 & 1.493 & & & & \\
\hline \multirow[t]{2}{*}{ NMC } & $\begin{array}{l}\text { Total } \\
\text { Posttest }\end{array}$ & 65.000 & 8 & 4.956 & 1.752 & \multirow{2}{*}{2.364} & \multirow{2}{*}{24.404} & \multirow{2}{*}{7} & \multirow{2}{*}{.000} \\
\hline & $\begin{array}{l}\text { Total } \\
\text { Pretest }\end{array}$ & 21.875 & 8 & 3.399 & 1.201 & & & & \\
\hline
\end{tabular}

Table 5 shows that the observed $t$ value was greater than the table value or critical value at all campuses. Similarly, Sig (2-tailed) or the value of probability was smaller than .05 at all campuses. It shows that there was a statistically significant difference in the total pretest mean score and the total posttest mean score of the Experimental Group at each campus. It shows the rejection of null hypothesis leading to the acceptance of the alternative hypothesis. It further justifies that the discussion teaching method was effective within each campus.

The researcher considered five campuses as a whole to investigate whether there was a statistically significant difference between the total pretest mean score and the total posttest mean score of the students of the Experimental Group or not. 
Table 6: Paired Variables: Total Posttest Score and Total Pretest Score Group: Experimental

\begin{tabular}{|l|l|l|l|l|l|l|l|l|l|}
\hline $\begin{array}{l}\text { Campus } \\
\text { es }\end{array}$ & Score & Mean & $\mathbf{N}$ & $\begin{array}{l}\text { Std. } \\
\text { Deviati } \\
\text { on }\end{array}$ & $\begin{array}{l}\text { Std } \\
\text { Error } \\
\text { Mean }\end{array}$ & $\begin{array}{l}\text { Table } \\
\mathbf{t} \\
\text { Value }\end{array}$ & $\begin{array}{l}\text { Observed } \\
\mathbf{t} \\
\text { Value }\end{array}$ & $\begin{array}{l}\text { Df } \\
\begin{array}{l}\text { Sig. } \\
\text { tailed } \\
\text { tailed }\end{array}\end{array}$ \\
\hline $\begin{array}{l}\text { As a } \\
\text { Whole }\end{array}$ & $\begin{array}{l}\text { Total } \\
\text { Posttest }\end{array}$ & 68.083 & 60 & 5.573 & .719 & \multirow{2}{*}{2.001} & 42.907 & 59 & .000 \\
\cline { 2 - 10 } & $\begin{array}{l}\text { Total } \\
\text { Pretest }\end{array}$ & 23.100 & 60 & 5.196 & .670 & & & \\
\hline
\end{tabular}

The pair samples $t$ test between the total pretest mean score and the total posttest mean score of the Experimental Group of campuses as a whole (observed t- value $=52.867$, critical $\mathrm{t}-\mathrm{value}=$ 1.983, $\mathrm{Df}=59$ and $\mathrm{Sig}$ (2-tailed) or $\mathrm{p}<.05$ shows that there was a statistically significant difference between the total pretest mean score and the total posttest mean score. It rejects the null hypothesis "there is no statistically significant difference between the Total Posttest and the Total Pretest Mean Scores of the students of the Experimental Group". It justifies that the discussion teaching method was effective within the Experimental Group (Table 6).

Power of Hypothesis Test in the Experimental Group

The researcher made use of G Power 3.1 Software to measure the power of the hypothesis test.

Table 7: Power of Hypothesis Test

\begin{tabular}{|lll|}
\hline \multicolumn{1}{|c|}{ T- tests - Means: Difference between two dependent means (matched pairs) } \\
Analysis: & Post hoc: Compute achieved & power \\
Input: & Tail(s) & Two \\
& Effect size dz & 5.5392118 \\
& $\alpha$ err prob & $=0.05$ \\
& Total sample size & $=60$ \\
Output: & Noncentrality parameter $\delta$ & $=42.9065501$ \\
& Critical t & $=2.0009954$ \\
& $=59$ \\
& Df & \\
& Power (1- $\beta$ err prob) & \\
& &
\end{tabular}

The power of the hypothesis test (1- $\beta$ err prob) as shown in the table was 1.000 which indicates that the test was considered to be working perfectly well. It implies that there was $100 \%$ chance of correctly rejecting the null hypothesis ( $\mathrm{H} 0)$ and accepting the alternative hypothesis $(\mathrm{H} 1)$ with 60 students (Table 7).

\section{Pretest and Posttest Mean Scores of Both Groups}

The mean value of the pretest and posttest scores was used to examine a general difference between these scores in each group and between the groups. 
ISSN: 2362-1303 (Paper) | eISSN: 2362-1311 (Online)

JOURNAL OF ADVANCED ACADEMIC RESEARCH (JAAR)

June 2019

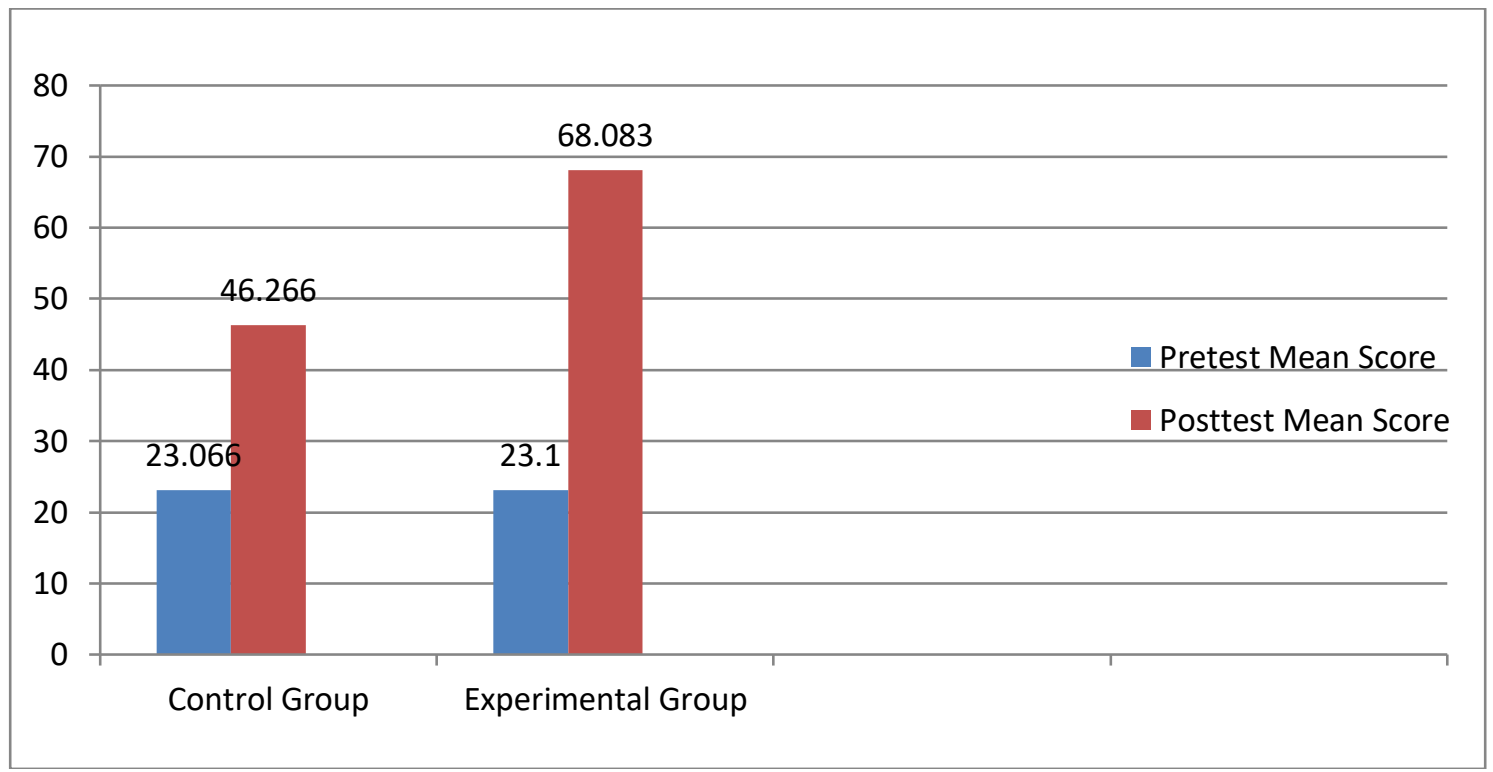

Figure 3: Pretest and Posttest Mean Scores of Both Groups

The Figure 3 shows that there was a significant difference between the pretest mean score and the posttest mean score within each group. The difference between the mean scores occurred because of the teaching methods applied to teach the students of both groups. It also justifies that the discussion teaching method was more effective than the lecture teaching method because the total posttest mean score of the Experimental Group ( $M=68.083)$ was greater than that of the Control Group ( $\mathrm{M}=46.266)$.

\section{CONCLUSIONS}

The pair samples $t$ test between the total pretest mean score and the total posttest mean score of the Control Groups and the Experimental Groups of all campuses confirms that both the lecture teaching method and the discussion teaching method were effective within each group. The null hypothesis that "there is no statistically significant difference between the Total Posttest and the Total Pretest Mean Scores of the students" was rejected, resulting in the acceptance of the alternative hypothesis that "there is a statistically significant difference between the Total Posttest Mean Score and the Total Pretest Mean Score of the Students". It can also be concluded that the discussion method was more effective than the lecture method.

\section{ACKNOWLEDGEMENTS}

We would like to thank the cooperating campus chiefs and English teachers of the respective campuses in Makawanpur District, Nepal for their convivial cooperation and altruistic interest in collecting the data, providing with students, managing the classrooms and creating suitable environment required for teaching learning activities to accomplish the research study. We are also thankful to the students for taking part in the study and providing their genuine responses to the questionnaire. 
ISSN: 2362-1303 (Paper) | eISSN: 2362-1311 (Online)

JOURNAL OF ADVANCED ACADEMIC RESEARCH (JAAR)

June 2019

\section{REFERENCES}

Abrams, M.H. (1993). A glossary of literary terms. Bangalore: PRISM BOOKS PVT LTD.

Al-Modhefer, A.K. \& Roe, S. (2009). Nursing students'attitudes to biomedical science lectures. Nursing Standard, 24(14), 42-48.

Al-Modhefer,A.K.\& Roe, S. (2010). Tutorials for large classes of common foundation program biochemical science students' sucesses and chalenges. Nurse Educatin Today, 30, 365-39.

Barber, C. (1985). Poetry in English: An introduction. London: Macmillan.

Braskamp, L.A., \& Ory, J.C. (1994). Assessing faculty work: Enhancing individual and instructional performance. San Francisco,CA: Jossy-Bass.

Brown, L. (ED.) (1993). The new shorter oxford English dictionary. New York: Oxford University Press.

Capon, N., \& Kuhn, D. (2004). What is so good about problem based learning? Cognition and Instruction, 22(1), 61-79.

Centra, J. (1993). Reflective faculty education. San Francisco, CA: Jossy-Bass.

Cuddon, J. A. (1999). Literary terms and theory. England: Penguin Book.

Harmon, W. (2009). A handbook to literature. New Delhi: Dorling Kindersley

Jarvis, P. (2002). The theory and practice of teaching. London: Kogan Publishing.

Jungst, Licklider , \& Wiersema. (2003). 5. Providing support for faculty who wish to shift to a learning-centered paradigm in their higher education classrooms. The Journal of Scholarship of Teaching and Learning, 3, 69-81.

Killen, R. (2007). Teaching strategies for quality teaching and learning. RSA: Shuman Printers.

Marbach-Ad, G., Seal, O. \& Sokolove, P. (2001). Student attitudes and recommendations on active learning. Journal of College Science Teaching, 30, 434-438.

Simpson, P. (2004). Stylistics. London: Routledge.

Stewart-Wingfield, S., \& Black, G.S. (2005). Active versus passive course designs: The impact on student outcomes. Journal of Education for Business, 81, 119-125.

Wales, K. (2001). A dictionary of stylistics. Harlow: Pearson Education Limited.

Whetten, D. A., \& Clark, S. C. (1996). An integrated model for teaching management skills. Journal of Management Education, 20, 152-181. doi:doi://10.1177/105256299602000202

Williams, D. (2002). Methods and style of teaching. Reading: UoR.

Wren \& Martin. (1981). High school English grammar and composition. New Delhi: S. Chand \& Company. New Delhi: S. Chand \& Company. 